\title{
MODERN METHODS OF VALUATION OF INVESTMENTS' ECONOMIC EFFICIENCY IN THE AGRICULTURAL BUSINESS
}

\section{Tudor BAJURA1, PhD, Professor, National Institute for Economic Research, Republic of Moldova}

The period of transition of the national economies from the socialist system to the market economy system is marked by a whole series of economic and social events, where investments represent a driving force for the country's economic development. The aim of this research is to provide scientific assistance on the widespread use of modern methods, recognized in developed industrialized countries, to elaborate and/or evaluate investment projects on the basis of which the indigenous agricultural sector will be able to survive in harsh conditions of often unfair competition from the part of Western agricultural producers. The main research methods are qualitative and quantitative analysis of economic events, comparative and statistical comparisons, dynamics and trend studies, economic and mathematical methods to justify the economic efficiency of investments, etc. The results obtained from the out carried research are the algorithms of calculation and performance indicators for assessing the level of economic efficiency of agrarian business investments, which are successfully used in the Western European countries for many years, but totally ignored within the national economy of the Republic of Moldova.

Keywords: evaluation, investment projects, modern methods, agrarian business, economic efficiency.

Perioada de trecere a economiei naţionale de la sistemul socialist spre sistemul economiei de piaţă este marcată de un şir de evenimente economice și sociale, din care, în mod deosebit, evidenţiem investiţiile - forță motrice pentru dezvoltarea economică a ţării. Scopul cercetării îl constituie asigurarea asistenţei știinţifice privind utilizarea largă a metodelor moderne, recunoscute în ţările industrial dezvoltate, de elaborare şi evaluare a proiectelor investiţionale în baza cărora sectorul agricol autohton va fi capabil de a supravieţui în condiţiile dure de competitivitate, deseori, neloială din partea producătorilor agricoli occidentali. Metodele principale de cercetare sunt: analiza calitativă şi cantitativă a evenimentelor economice, comparaţiile pare şi cele statistice, formarea rândurilor dinamice şi studiile trendurilor, metodele economico-matematice de argumentare a eficienţei economice a investiţiilor etc. În calitate de rezultate, obţinute în urma cercetărilor efectuate, pot fi numite algoritmele de calcul şi indicatorii de performanţă privind evaluarea nivelului de eficienţă economică a investiţiilor în businessul agrar, care, ani la rând, sunt utilizate cu succes în ţările vest-europene, însă, practic pe deplin, ignorate în cadrul economiei naţionale a Republicii Moldova.

Cuvinte-cheie: evaluare, proiecte investiţionale, metode moderne, business agrar, eficienţă economică.

Период перехода национальной экономики от социалистической системы к системе рыночной экономики отмечен целым рядом экономических и социальных событий, одним из которых следует признать инвестиции, являющиеся движущей силой экономического развития страны. Цель исследования - оказать научную помощь в широком распространении современных методов, применяемых в промышленно развитых странах, для разработки и оценки инвестиционных проектов, с помощью которых местный сельскохозяйственный сектор сможет выжить в непростых условиях зачастую нелояльной конкуренции со стороны западных сельхозпроизводителей. Основными методами исследования являются качественный и количественный анализ экономических событий, статистические сравнения, исследования динамических рядов и сформированных на их основе трендов, экономикоматематические методы обоснования экономической эффективности инвестиций и др. 
В качестве результатов, полученных на основе проведенных исследований, можно назвать алгоритмы расчета и оценочные показатели уровня эффективности инвестиций в аграрный бизнес, которые годами успешно используются в странах Западной Европы, но практически полностью игнорируются в рамках национальной экономики Республики Молдова.

Ключевые слова: оценка, инвестиционные проекты, современные методы, агробизнес, экономическая эффективность.

DOI: https://doi.org/10.36004/nier.es.2019.1-02

JEL Classification: G11, 013, Q10, Q13, Q16, Q19

$U D C: 338.43+330.322: 631.15$

Introduction. There are almost three decades since the declaration of independence of the Republic of Moldova (August 27, 1991). During this period, many sectors of the national economy have been successfully adapted to the new conditions of economic activity, based on the market mechanisms and management, primarily those with private ownership above the means of production, including agricultural land. As a result of the permanent reduction of the number of people employed in agriculture, at present only $32.3 \%$ of the total number of employees in the national economy are agricultural workers. One of the key factors, contributing to the low level of attractiveness of jobs in agriculture, is the lack of permanent (year-round) jobs, and most importantly, significantly lower wages, which do not exceed $2 / 3$ of the average for the national economy, even in the most demanding period of the year (season of the most intensive agricultural works).

Investments in the agricultural sector are intended to increase and improve the production capacities of farms, to contribute to the increase of standards of living in rural areas, as well as poverty alleviation. Well-defined and well-thought investment projects in the agricultural sector could contribute to the development not only of the economic agent involved in the sector, but will have positive impact also on the population from a certain area where the project is implemented.

The aim of the paper is to offer a scientific approach to the investment projects in agriculture, which is also a novelty in this field, as previous research on this specific topic in the Republic of Moldova is not sufficient and has not been studied at a large extent.

Even if the study bears a theoretical character, providing methods of assessment of investment projects, its applied feature can not be denied, due to the fact that the calculations provided in the research can be further used is order to assess a specific investment object.

The degree of scientific approach to the topic and its presentation in the scientific literature. The detailed analysis of the degree of depiction of the problem in question, i.e. assessment of the investment projects in the agricultural sector, in the scientific literature of the Republic of Moldova serves as the basis of a univocal conclusion that fragmented analysis of the problems of efficiency of the investment activity have been adequately reflected in the researches of the local scientists. For example, Svetlana Albu [5] investigated the issues of the assessment and management of the national heritage; the problems of work organization and efficient agricultural management were studied in depth by the Moldovan scientists - Petru Turcanu, Alexandru Stratan, Dumitru Parmacli, Natalia Mocanu, Elena Timofti and others $[6 ; 7 ; 8 ; 9 ; 10]$. At the same time, the efficiency aspect of investments in the agrarian sector, approached as an initial stage of shaping the future agricultural potential, with the application of truly modern Western methods, was undertaken in one paper [11], which obviously is not sufficient and do not ensure adequate resolution of the issue of efficiency of investments in agriculture.

Data sources. The database of the initial information was composed by the monographs, articles, textbooks, etc. both of the scientific workers and university teachers, as well as the works of foreign scholars in the field of investment efficiency, evaluation of real estate objects, including agricultural land. Besides this, the data provided by the National Bureau of Statistics of the Republic of Moldova was consulted, which is properly reflected in the statistical yearbooks for the respective years. Nevertheless, the paper uses a personal scientific approach of the author, who provides a set of methods of evaluation of investment projects in the agricultural sector.

Results and discussions of scientific research. Unlike a number of ordinary purchases, which each of us makes, almost daily, without even thinking about their rationality or irrationality, 
investment expenditures require a more deeply and comprehensively weighed preliminary justification.

Taking into account some specific existing features, there are many reasons for a detailed initial analysis of future investments, the main ones being as follows:

- investments are made, as a rule, for a long term and are often deprived of the possibility of a "reverse motion";

- all investment projects usually require essential financial expenses and, therefore, in addition to its own funds, the investor usually also requires borrowed financial resources;

- large relative and absolute costs, as well as long periods for the implementation of investment projects, determine their increased level of risk;

- due to limited financial resources and almost unlimited opportunities for investments, each investment proposal currently has, as a rule, not one, but several alternatives, making it difficult for the investor to take a final decision.

From the above list of main reasons for pre-investment analysis, we can conclude that there are many potential options for investment. It may seem strage, but this polyvariance of potentially existing directions of investment, in the end, hinders the process of making argumented final investment decisions.

In order to overcome the contradiction mentioned above, the present study assumes the use of a diversified system of indicators capable to identify clearly the most effective investment option for each particular case, from the many available alternatives.

As an initial stage of substantiation of future investment decisions, we consider the market of agri-food products, which includes a wide range of goods and services for the production, processing, storage, transportation and sale of both raw agricultural materials and ready-to-eat final products.

The market of agri-food products: current state and development prospects. The market of agricultural products is closely related to the market of food products, for which it delivers the main part of raw materials and serves as the natural basis for the formation of the latter, but does not duplicate it. The essence of the difference lies in the well-known diversity of both agricultural and food products, their wide diversification and constant renewal. At the same time, an increasing proportion of agricultural products find their final consumption outside the food market (for example, the production of biofuels). In turn, a very dynamic development is observed in areas of food production that are alternative to agriculture (hydroponic cultivation of vegetables, production of synthetic types of protein, suitable for nutrition, etc.).

Due to the differences mentioned above, retaining the property of a whole, the agri-food market is divided into (i) the market of agricultural goods and services, as well as (ii) the food market.

The next distinguishing feature is the fact that both of them: the national and the global level of agricultural market, in the quality of a specific fragment of the market economy (as a whole), steadily provides the largest number of jobs. Also, in the third world countries (including the Republic of Moldova), the agricultural market provides the largest volume of market turnover (in terms of money) compared with the other sectors of economic activity.

Thus, according to the latest statistics (as already noted), the agricultural sector of the national economy (agriculture, forestry and fish farming) provides jobs for 390 thousand people, which is $33.7 \%$ of the total employed population. Together with the workers in industry, transport and trade, the total number of workers engaged in the production, processing, transportation and sale of agri-food products exceeds 570.0 thousand people, which is approximately $46.7 \%$ of the total number of people from those employed in the national economy. At the same time, the volume of agricultural production in 2017 amounted to 33.0 billion lei, and the retail turnover of food products -18.2 billion lei, or $37.4 \%$ of the total retail turnover. Particularly noteworthy is the steady increase in the share of food products in the total retail turnover in recent years.

Given the fundamental importance of this trend, primarily for those who will make the final decision on investments in agribusiness, it should be noted that it is based on:

- massive movement of rural residents to cities and municipalities of the Republic of Moldova after the completion of the privatization of agricultural land and other fixed assets of the agriculture, which took place in 2000; 
constant growth in the purchasing power of an ever-increasing number of citizens living in urban areas, due to both, a general increase in the standard of living and higher labor productivity (and, consequently, the wage for it) in non-agricultural sectors of the national economy.

Against the background of the all above mentioned, it should be noted also the dynamic and stable growth of the level of marketability of agricultural production, which reached (by the end of 2017) $-47.5 \%$, which is a record for domestic agriculture.

In addition, according to the results for 2017, the profitability of sales of agricultural enterprises, noted by the statistical bodies, was with 2.2 percentage points higher than the average level of this indicator in the national economy and amounted to $21.1 \%$ in average annual terms [1, table 22.13.].

At the same time, there are substantial reserves for the growth of both agricultural productivity and the volume of retail turnover of food products, respectively, per average annual worker or per capita (Table 1).

Labor productivity in agriculture and the volume of retail turnover of food products

\begin{tabular}{|c|c|c|c|c|}
\hline \multirow[b]{2}{*}{ Years } & \multirow{2}{*}{$\begin{array}{l}\text { Gross domestic } \\
\text { product (market } \\
\text { prices) per capita, } \\
\text { lei / year }\end{array}$} & \multirow{2}{*}{$\begin{array}{l}\text { Labor productivity } \\
\text { per one average } \\
\text { annual agricultural } \\
\text { worker, lei / year }\end{array}$} & \multicolumn{2}{|c|}{ Retailing food products } \\
\hline & & & $\begin{array}{l}\text { per capita, } \\
\text { lei / year }\end{array}$ & $\begin{array}{c}\text { per one average annual } \\
\text { agricultural worker, } \\
\text { lei / year }\end{array}$ \\
\hline 2000 & 3741.6 & 10807.8 & 952.4 & 1886.2 \\
\hline 2005 & 10457.7 & 23627.6 & 1004.5 & 6725.1 \\
\hline 2010 & 20171.5 & 63088.9 & 2259.7 & 25553.0 \\
\hline 2015 & 34503.4 & 71185.9 & 4354.7 & 40528.3 \\
\hline 2016 & 38106.7 & 73873.5 & 5112.4 & 44196.8 \\
\hline 2017 & 49783.7 & 87543.6 & 5115.6 & 50922.8 \\
\hline
\end{tabular}

Source: Statistical Yearbook of the Republic of Moldova for relevant years.

The main estimates, made on the data of table 1 are:

- if at the beginning of the period (2000) the labor productivity in the agricultural sector was only 10.8 thousand per worker, per year, then at the end of this period (2017), the labor productivity level in the agricultural sector was already 87.5 thousand or 8.1 times higher;

- the growth in the productivity of agrarian labor was relatively high, but the retail turnover of food products per agricultural worker increased (for the period analyzed in Table 1) even more rapidly - by 27.0 times compared to the beginning of this period (2000). Correspondingly, if at the beginning of the period the productivity of one worker, achieved in domestic agriculture, allowed us to satisfy the needs of approximately 2 people, then at the end of the period (2017) this indicator was already nearly 10 people;

- it is quite obvious that substantial growth in both labor productivity in agriculture and the retail turnover of food products per one average annual worker in this sector, for the entire analyzed (post-privatization) period were achieved, first of all, due to a reduction in the number of employees (from 766 thousand people in 2000 to 390 thousand people in 2017).

Despite the positive dynamics of the main indicators of the development of the food products market in the Republic of Moldova, achieved as a result of relatively high growth rates of agricultural labor productivity, in turn, based on private ownership, these indicators are still significantly inferior to many similar indicators of industrialized countries from Western Europe and North America.

This circumstance serves as the starting point of the statement about the existence of substantial reserves for increasing both labor productivity and other quantitative and qualitative indicators of the development of the domestic agri-food sector, including crop yields, animal and poultry productivity, growth in the level of profitability of the agricultural business, etc. It has to be underlined that permanent relative and absolute reduction in the number of rural population, which leads to a stable decrease in the number of agricultural workers, irrefutably testify the need for a smaller number of workers to assure with high-quality and diverse food the increasing number of 
urban population. Therefore, it is impossible to achieve such results without the help of investments aimed at:

- the acquisition and practical use of modern technologies for the cultivation of crops (raising animals and poultry), including new highly productive and resistant to stress factors plant varieties and breeds of animals and poultry;

- introduction of the most advanced organizational forms and methods of agricultural production, integrated into a single (cross-cutting) technological chain - "from the producer's field / farm to the consumer's table";

- selection, justification and practical application of optimal composition of production structure, levels of its specialization and/or concentration, allocation of capital in the most efficient for these specific conditions sub-sectors of agricultural production.

Even this small list of possible solutions to the problem of capital investments clearly indicates the need for a detailed, scientifically based and practically proven guide in the field of agribusiness investments. The presence of many options for investment decisions, as has already been stressed out, does not simplify but, on the contrary, complicates the management decision-making process, making it fragmentary, based, at best, on the experience of other investors, at worst - on intuition or simply by occasionally appearing information.

Nevertheless, the implementation of capital investments should be based on systemic, strictly reasonable and reliably verified calculations. Modern scientific concepts of financial and, above all, investment management really serve as the theoretical basis for making management decisions in the field of investment. The advantage of these concepts lies in the fact that regardless of their internal content, they are all deprived of an ideological background, contain no political preconditions and are capable of justifying the final results of various investment decisions with a high degree of probability.

In contrast to the overwhelming majority of previously published and practically applied methods for determining the effectiveness of investments, such practical guidance for making management decisions in the field of agribusiness involves evaluating the effectiveness of investments, based on actualized (discounted) cash flows, generated by one investment project or another.

Calculation of investment efficiency based on financial flows. It is considered that the accounting department of the enterprise (company) should answer all the questions regarding the existing and/or future investments. In fact, among the many types and forms of financial statements there is a report "On cash flow", which, in principle, should contain information about all investment projects of the company. Naturally, about all existing, for which the accounting department of the company has clearly established (fixed) costs and final (received) results.

If we are talking about newly emerging investment projects, accounting data on them, of course, does not exist. Therefore, the relevant information should be contained in the project itself. Moreover, reputable enterprises (mainly corporate structures) in order to make truly objective, well and comprehensively weighted investment decisions, as a rule, require the development of not one, but several, so-called alternative projects.

As a result, based on modern theoretical developments, the most progressive (corporate) practice of financial management regarding investment politics decisions is based on the expected provision (by relevant projects) of the cost-benefit ratio, measured by calculating former and future cash flows (CF).

From the above mentioned, it follows that the calculation of cash flows assumes coverage of all types of costs from previous periods (for example, years) and even more complex accounting of cash inflows from future periods. The difficulty lies in the fact that both of these periods (past and future) are very long. As a rule, they are measured in years, and in some cases - in decades of years. A significant part of investment projects (for example, the purchase of land) has no time limit at all. It is well known that, unlike many other types of fixed assets, used in agribusiness, a land plot (in case of its rational use) not only does not lose its biological (read - fertile) qualities but, on the contrary, multiplies them. For this reason, (in particular) land plots are not subject to depreciation, which makes them particularly attractive as an object of investment. 
The method of measuring and comparing cash flows is not the only one decision-making method in the field of scientific argumentation of investments. Many investment projects (especially in the pre-reform period of development of the national economy) were developed and implemented in order to solve purely applied tasks, for example, to ensure the production of grain crops at least 1 ton per each citizen of the country per year.

Another widely known, but no less ideological, approach to making decisions in the field of investments is the method of comparison. As a rule, separate, previously achieved indicators of different countries (regions) are compared, which in itself is methodologically erroneous, given the huge number of existing factors, the differences between which make the comparison method practically unacceptable.

As will be shown later, the cash flow investment decision making method is also based on separate comparison fragments. However, in this case we are talking about comparing the cost streams with the revenue streams, provided by these costs. The integrity of the investment project, as an object of research, more precisely, the object of evaluation of the designed investment, is not violated here, which leads to the exclusion of the possible (positive or negative) influence of external factors.

Calculation of cash flows for the development of investment projects. As already noted, the theoretical basis for the development of modern investment projects are cash flows, consisting of:

- construction costs of the investment object;

- current operating costs occurring during the operation of the investee;

- revenue, and ultimately - the net income, received as a result of the operation of the investment project.

Taking into account the fact that between the start of project development and the receipt of future outcomes there is usually a significant (in time) period, it is important that the planning and pre-planning calculations take into account real-life needs of expenditure, as well as the most reasonable cash receipts, due to these costs (equally investment and current).

The main source of information for calculating investment costs is a cost estimate (technological maps) for laying a unit of an orchard, vineyard, greenhouse, farm, etc.

If the investment project provides for the production and sale only a single type of product (for example, production of plums for fresh sale), then planning cash flows at the beginning of the project can be simplified, considering the rise in the selling price in proportion to the expected rate of inflation for the entire period of the project.

However, in the overwhelming majority of cases, the quantity of produced products will be significantly more than one (due to the need to respect the crop rotations, the rational use of acquired technical means, the available labor, etc.). In this regard, it is recommended to calculate the average value of cash flows (monthly operating costs and net cash proceeds) for the first year of operation of the project according to Table 2. In subsequent years, the performance of the project is expected to be estimated by the average rate of increase in costs and an adequate increase in outputs (final results), based on the expected yield increase and the dynamics of changes in selling prices, taking into account the level of inflation.

The payback period and the coefficient of efficiency of investment in case of the "zero" level of inflation. As a commentary to the title of this section, it should be noted that for various reasons, which do not depend on the choice of investor, each investment project will be implemented either in the inflation or deflationary economic system.

"Inflation" means the depreciation of money, accompanied, as a rule, by an increase in prices for goods and/or services. The economic essence of inflationary phenomena is widely covered in the special literature, so we will not describe it. We only emphasize once again that, unlike deflation, which, on the contrary, represents an increase in the purchasing power of currency notes and, as a result, a decrease in prices for goods and/or services, the inflation scenario of the development of the national economy is more attractive for investors.

Taking into account the availability, magnitude and trends of a number of pricing factors, as well as factors of profit (loss), debt, economic growth, etc. the current financial and economic state of the Republic of Moldova can be characterized as stably inflationary with a gradual approach to the "zero" level of inflation and the subsequent transition to a deflationary scenario of economic development. 
Considering all the above mentioned, and also taking into account the experience of other countries, primarily Japan, the period of attaining the state of "zero" inflation for the Republic of Moldova is measured for at least decades.

Table 2

\begin{tabular}{|c|c|c|c|c|c|c|c|c|c|c|c|c|c|c|}
\hline \multirow{2}{*}{$\begin{array}{c}\text { Name of } \\
\text { crops }\end{array}$} & \multirow{2}{*}{$\begin{array}{c}\text { Expendit } \\
\text { ure of } \\
\text { previous } \\
\text { periods }\end{array}$} & \multicolumn{12}{|c|}{ Month } & \multirow[t]{2}{*}{$\begin{array}{l}\text { Total for } \\
\text { the year }\end{array}$} \\
\hline & & 1 & 2 & 3 & 4 & 5 & 6 & 7 & 8 & 9 & 10 & 11 & 12 & \\
\hline \multicolumn{15}{|c|}{ Cash inflow } \\
\hline $\begin{array}{c}\text { Winter } \\
\text { wheat. } \\
\text { Other } \\
\text { cultures ... }\end{array}$ & & & & & & & & & 2820 & & 328060 & & & 330880 \\
\hline $\begin{array}{c}\text { Total } \\
\text { receipts }\end{array}$ & & & & & & & & 103500 & 274280 & 776200 & 532400 & 976000 & & 2662380 \\
\hline \multicolumn{15}{|c|}{ Cash costs } \\
\hline $\begin{array}{c}\text { Winter } \\
\text { wheat. } \\
\text { Other } \\
\text { cultures ... }\end{array}$ & 56748 & & & 5818 & 13516 & 15170 & 5850 & & & & & & & 97102 \\
\hline $\begin{array}{c}\text { Total } \\
\text { variable } \\
\text { costs }\end{array}$ & 193485 & & & 84731 & 78657 & 116576 & 106554 & 73981 & 44878 & 168413 & 19861 & & & 887136 \\
\hline $\begin{array}{l}\text { Fixed costs, } \\
\text { total }\end{array}$ & & 11499 & 11499 & 19269 & 11499 & 11499 & 19269 & 27139 & 11499 & 19269 & 11499 & 11499 & 182122 & 347461 \\
\hline Total costs & 193485 & 11499 & 11499 & 104000 & 90156 & 128073 & 125823 & 101020 & 56377 & 187682 & 31360 & 11499 & 181122 & 1234597 \\
\hline \multicolumn{15}{|c|}{ Cash flow } \\
\hline $\begin{array}{l}\text { Availability } \\
\text { of money } \\
\text { at the } \\
\text { beginning } \\
\text { of the } \\
\text { period }\end{array}$ & & -193485 & -204984 & -216483 & -320483 & -410639 & -538715 & -664537 & -662057 & -444154 & 144364 & 645404 & 1609905 & $\mathrm{x}$ \\
\hline Arrival (+) & & - & - & - & - & - & - & 103510 & 274280 & 776200 & 532400 & 976000 & - & 2662380 \\
\hline Expenses (-) & -193485 & -11499 & -11499 & -104000 & -90156 & -128073 & -125823 & -101020 & -56377 & -187682 & -31360 & -11499 & -181122 & -1234597 \\
\hline $\begin{array}{c}\text { Availability } \\
\text { of money } \\
\text { at the end } \\
\text { of the } \\
\text { period }\end{array}$ & -193485 & -204984 & -216483 & -320483 & -410639 & -538715 & -664537 & -662057 & -444154 & 144364 & 645404 & 1609905 & 1427783 & $\mathrm{x}$ \\
\hline
\end{tabular}

Source: Author`s calculations.

It is important to clarify that from the point of view of investors and the investment process as a whole, this period is the most favorable for acquiring or/and opening an "own business", obtaining the status of social and financial independence, characteristic for every successful entrepreneur. This clarification is necessary because the essence of the "deflationary economy" scenario, in scientific circles and among entrepreneurs, is consistently associated with the state of stagnation, a return to the administrative methods of economic management. These are quite familiar to older businessmen who laid the foundations of their business back in the 80's of the last century or in the early years of mass privatization in the Republic of Moldova (the end of last century).

As already noted, even theoretically, on the verge of a transition from an inflationary to a deflationary economy, a so-called "zero" inflation period should exist and indeed exists (albeit rather short). What does this period mean, what are its main parameters and characteristics?

The content of this question, as well as the answer to it, has its clear theoretical expression. However, for the purposes of this management (decision-making) oriented article, it is more important to identify the purely practical (applied) essence of the identified problem.

The essence of the state economy at the level of "zero" inflation, as well as (equally) - "zero" deflation, is that during this period both - the purchasing power of banknotes and the actual market prices for goods and services remain unchanged, absolutely stable.

Non-systemic (for example, local, sectoral, etc.) deviations from this stability, of course, can occur. But they will be nothing more than exceptions, which, as we know, only confirm the existence 
of a rule. The rule remains itself - the purchasing power of banknotes in the period of "zero" inflation does not change in time, prices for goods and services also remain unchanged. The economy operates in conditions of stable purchasing power of banknotes.

From the point of view of the appraiser of the effectiveness of investments, this is the most simplified version. Since inflation (as well as deflation) is absent, all types of investment costs, regardless of the statute of limitations for their implementation, add up to a total amount (like children's blocks) without any adjustment and without any amendments to the preceding dimensions.

The same thing happens with the end results, obtained from the operation of certain investment projects. Since this is a "clean" end result, i.e. result, cleared of inevitable current costs, which boils down, in principle, to revenue (usually annual) minus all types of operating (i.e., associated with the operation of the name of this investment project) costs. These "clean" results in these conditions (i.e., "zero" inflation conditions) also add up to a single amount like a house of children's cubes without a single adjustment for the length of the period, separating the capital investment in a particular project from the really obtained profit of its exploitation.

Then, by comparing the obtained "net" results with the previously implemented total investment costs, we determine the payback period of the invested funds, as well as the level of their economic efficiency. We remind you that such a calculation is justified and makes sense only if there is a "zero" inflation, that actually takes place (or simply assumed - in the case of preliminary or test calculations).

Exceptions to this limitation may be situations when the investment project being analyzed and/or estimated in short-term period (within $3 \div 5$ years), or the inflation rate in this period is absolutely insignificant - within $2 \div 3 \%$ per annum.

The calculation of the payback period of investments (Payback Period - Tp.p.) is carried out separately for the depreciable components of the investment project and separately for nondepreciable. For non-depreciable components, the calculation of Tp.p. is conducted according to the formula:

where:

$$
T_{p . p .}=\frac{I C}{P_{a v . a n .}} \text { (years) }
$$

$I C$ - the initial cost of investment, lei;

$P_{\text {av.an.- }}$ average annual "net" cash flow due to the operation of this (non-depreciable) component of the investment project, lei / year.

If the average annual "net" cash flow is calculated for the depreciable part of the project, the size of the average annual "net" cash flow is increased by the amount of annual depreciation.

Example: An investment project with a cost (IC) of 110 thousand lei ensures profit (net income) in the amount of (thousand lei): 1 year - 50; 2 year - 46; 3 year - 40; 4 year - 30; 5 year - 26. It is required to determine the payback period of this project in the conditions of "zero" inflation.

1. Determine the net average annual income from the operation of above mentioned investment project:

$$
P_{\text {av.an. }}=\frac{50+46+40+30+26}{5}=38.4 \text { thousand lei / year }
$$

2. The payback period of investment project is:

$$
T_{p . p .}=\frac{\mathrm{IC}}{\mathrm{P}_{\text {av.an. }}}=\frac{192}{38.4}=5.0 \text { years }
$$

Calculation of the payback period of investment projects in the conditions of "zero" (really existing or simply assumed) inflation is an effective and most simplified part of any analysis (any assessment) of investment activity. Due to its simplicity and the absence of the need to use complex mathematical tools, this calculation must necessarily precede any form of investment calculation, regardless of its size (volume), industry sector, etc. It should also be emphasized that the calculation of the payback period is an important first step in choosing the most effective project among the many others - alternative ones. 
At the same time, having a number of advantages and being widely used in the practice of developing and making investment decisions, the payback period of investments as an analytical and estimated indicator has significant drawbacks. Along with those mentioned above, another one should be noted, which is very important from the point of view of practical solutions.

The payback period does not give an answer to the question of how much this or that final result of investment activity is achieved. However, in reality, in addition to information about the size of invested capital (IC) and the payback period (Tp.p.), it is also very important for the investor to know which are the main parameters of the project's economic efficiency, in particular - what is its average annual (and final) efficiency. The essence of the problem lies in the fact that not a single investment project, as a rule, can do without attracting borrowed capital, for which, as we know, an investor has to regularly pay a certain percentage. Following this logic, it is reasonable to assume that even if the investor has sufficient capital to implement the project, this investment source is also not free of charge. The investor's own funds have been, deposited at a bank account, could bring him a certain income, which (in this case) is the cost of the investor's own capital.

In other words, any investment proposal may be acceptable provided that its efficiency (i.e. return on invested capital) will be higher than the cost of this capital.

Therefore, for non-depreciable components of investment projects, the efficiency of invested capital is calculated by the formula:

$$
A R R=\frac{P_{a v . a n .}}{I C} \times 100 \quad(\%)
$$

where:

$A R R$-Accounting Rate of Return - ARR, \%;

$P_{a v . a n .}$ and $I C$ - the average annual net cash income and the initial investment cost, respectively [2].

For depreciable components of investment projects (or for depreciable projects subject to depreciation as a whole), formula (2) takes the following form:

$$
A R R=\frac{P_{a v} \cdot a n .}{0,5 \times I C} \times 100 \quad(\%)
$$

if at the end of operation of the project its residual value is zero, or:

$$
A R R=\frac{P_{a v . a n} .}{0,5 \times(I C+R V)} \times 100 \quad(\%)
$$

if the residual value (RV) is greater than zero. In both of the above mentioned cases when calculating $\mathrm{P}_{\mathrm{av} . a n .}$ along with the net operating income, the average annual amount of accrued depreciation has also to be taken into account.

In a market economy, there are no officially established lower and/or upper (minimum or maximum) limits of ARR. Despite this, the minimum level of the efficiency of capital investments, naturally, can not be lower than the average rate of credit, delivered for the national economy in the banking system, which in the Republic of Moldova currently stands at 8.6\% per annum. Taking into account the fact that both of the above mentioned indicators (Tp.p and ARR) are significant only in the conditions of "zero" inflation and focusing on their reciprocal value, one would expect to make positive decisions on all investment projects whose payback period on average does not exceed 11.6 years $\left(\frac{100}{8,6}=11,6\right)$.

However, in conditions of even moderate inflation, these calculations can lead to erroneous results. As it is well known, under the influence of inflation the efficiency ratio of capital investments decreases, while their payback period, on the contrary, increases.

Methodical approaches to the calculation of the capitalized (future) value of investments in terms of inflation. In the conditions of a market, and even more than that - a market inflationary economy, the ultimate goal of any investment project is to increase the investor's capital. In turn, this multiplication is possible only in the case of successful project operation, meaning a constant and very significant (especially in the conditions of substantial inflation) excess of income over costs, both of which are measured in current prices of the respective years. 
The next important feature of calculating the multiplied (capitalized, future, final, etc.) value of investment projects is the need to separate the cash flows caused by a particular project into at least two qualitatively (and quantitatively) different directions:

- the first direction (we will consider it the main one) is that part of the money received, which the investor does not intend to divert to other goals, leaving it to further strengthen and accelerate the development of the business (project);

- the second direction is the funds recovered (received) as a result of the successful operation of the project, which are constantly (or periodically) diverted by the investor to solve other problems that have nothing to do with the analyzed (estimated) investments.

The most of the net cash income (from the project) will be used in the second direction, the less will be the end result of its functioning.

Typical for successfully operating investment projects is the division of the resulting total net income of the investment project in half: $50 \%$ of the funds are used for further development (expansion, modernization, diversification, etc.) of the basic project; $50 \%$ - to solve other problems, including the payment of dividends to the owner (co-owners), encouraging managers of the enterprise and other goals.

It is quite obvious that the subsequent return of the newly invested (reinvested) in the investment project and/or the funds diverted from it for other needs will be completely different. The methods for calculating the capitalized value are also different for each of the listed ways to use the received net income.

In the case of reinvestment of funds in the development of the project, the calculation of the final results of investment activity is carried out on the basis of a compound interest formula (Compound Rate of Return - CRR).

If the funds received as a result of the effective (profitable) activity of the project are not reinvested in the development of the project, but are diverted to other goals and/or needs of the owner of the company (including to solve his personal problems), the calculation of the final (capitalized) project cost is effectuated on the base of simple interest formula (Simple Rate of Return - SRR).

Before proceeding directly to the essence of the above mentioned methodological approaches to the calculation of the final (capitalized) or future project value (Future Value - FV), let us take a closer look at some specific fragments of separate accounting of cash flows, generated by a successfully functioning investment project.

First of all, it should be noted that the distinction between the cash flows generated by the investment project is clearly reflected in the documents of the company's accounting statements. The amounts of money sent for the development of an enterprise are reflected in the balance sheet on the liabilities side under the name "Retained earnings", which naturally increases from year to year. Also the report on retained earnings reflects the monies paid to the owners of the enterprise (project) in the form of dividends, which, in turn, will be used for personal purposes and the needs of investors (founders or simply co-owners of the enterprise).

As a separate note, it should be emphasized that "Dividends received" and "Retained earnings" are only the part of the existing forms of returning money to capital, invested in an investment project. The part of revenue returned to owners funds is also replenished due to depreciation deductions and, to a large extent, due to the remuneration of labor of both the investor(s) and their family members. Despite the fact that both of these sources belong to the category of costs of the enterprise, and their practical transformation into monetary form occurs only at the time of sale of manufactured products in the respective sales markets, for the vast majority of potentially existing investors in agribusiness they are an essential additional source of income.

Returning to the question of methodological approaches to the calculation of the future, or accumulated (capitalized) income, depending on the direction of use of the resulting return, we note the following:

a) The received cash income is completely reinvested in a valid investment project. In this case, as it was already mentioned, we will use the algorithm of Compound Rate of Return (CRR):

$$
R_{n c}=P_{o} \times(1+r)^{n} \text {, lei }
$$

b) The received cash income is completely distracted from the existing investment project and is directed to other goals and needs.

In this case the algoritm of Simple Rate of Return - SRR, will be: 
where:

$$
R_{n s}=P_{o} \times(1+r n) \text {, lei }
$$

Rnc (CRR) and Rns (SRR) are respectively the capitalized (future) value of the investment project, calculated (option "a", formula 5) using the compound interest rate of return formula and (option "b", formula 6) using the simple interest rate of return formula (lei);

$\mathrm{Po}=\mathrm{IC}$ is the initial cost of the investment project, lei;

$r$ is the established level of profitability of an investment project (specific units);

$\mathrm{n}$ is the number of operation periods of the project and, accordingly, the number of periods for calculating the capitalized value.

Analyzing the content of formulas (5) and (6), at first glance it becomes clear that if the number of calculation periods is one (only), then the results of the calculations in both cases will be the same. In all other cases, however, these results will be significantly different.

The difference between the above mentioned two methods of calculating the accumulated (capitalized or future) value will be considered on a specific example.

Example: It is required to calculate the final amount of capital accumulation obtained as a result of making an investment in the amount of 1000 lei, if used: a) compound interest rate formulas; b) simple interest rate formulas, taking into account the following conditions: $r_{a n}=20 \%$; settlement periods are: 90 days; 180 days; 1 year; 5 years; 10 years (a year has 360 days) [3]. The calculation results are summarized in table 3 (fig. 1).

Table 3

\section{The results of the calculation of the capitalized (future) value of the investment, depending on the number of calculation periods and methods, thous. lei}

\begin{tabular}{|l|c|c|c|c|c|}
\hline \multicolumn{1}{|c|}{$\begin{array}{c}\text { Algorithm } \\
\text { (method) of } \\
\text { calculation }\end{array}$} & $\begin{array}{c}\mathbf{9 0} \text { days } \\
\mathbf{n = 1 / 4}\end{array}$ & $\begin{array}{c}\mathbf{1 8 0} \text { days } \\
\mathbf{n = 1 / 2}\end{array}$ & $\begin{array}{c}\mathbf{1} \text { year } \\
\boldsymbol{n = 1}\end{array}$ & $\begin{array}{c}\mathbf{5} \text { years } \\
\mathbf{n = 5}\end{array}$ & $\begin{array}{c}\mathbf{1 0} \text { years } \\
\boldsymbol{n}=\mathbf{1 0}\end{array}$ \\
\hline $\begin{array}{l}\text { a) compound } \\
\text { interest rate } \\
\text { formula; }\end{array}$ & 1,0466 & 1,0954 & 1,20 & 2,4883 & 6,1917 \\
\hline $\begin{array}{l}\text { b) simple interest } \\
\text { rate formula }\end{array}$ & 1,05 & 1,10 & 1,20 & 2,00 & 3,00 \\
\hline
\end{tabular}

Source: Elaborated by the author.

Thus, as follows from the above reflected example, if the interest accrual period is less than one, then the calculation using the simple interest rate formula gives a larger final result, compared to the compound interest rate formula. If the number of charges is greater than one, then the result of the calculation of the accrued amount will (with time) significantly exceed the results of alternative calculations, in this case, calculations made according to the simple interest rate scheme.

With ten periods of calculation, as follows from above mentioned example, the accrued amount of an investment project (calculated according to the compound interest rate scheme) will more than double the same result, obtained using the simple interest rate scheme. In the economic literature, this phenomenon is characterized as "calculation of interest on interest", suggesting that, according to option "a", the investor does not withdraw money from his project, expecting them to increase more and more as a result of capitalization of the accrued amounts of money.

If we depict the situation graphically, then it is quite obvious that the simple interest rate method will reflect a steady increase of capitalization in an arithmetic progression. In other words, by the end of the ten-year period, the total amount of money will increase threefold and reach 3,000 lei (although on the project will still be the original amount of 1,000 lei).

As for accumulation under the compound interest rate scheme, it is also quite obvious that by the end of the 10-year period, the total amount of money will exceed the initial amount by almost 6.2 times (6191.7 lei), the total volume of money will increase exponentially. In both cases, however, the greater the growth rate will be, the larger the total amount of money, accumulated in the framework of investment project. 
Another example of using simple interest rate to calculate the capitalized value is the lease of a land plot, as a result of which the land owner uses all received rental payments, for his own, let's say, purely personal purposes. If, suppose, the same amounts of cash payments are used by the lessor to make the necessary improvements (for example, irrigation of the plot), then we should expect a subsequent increase in the amount of rent, which should be regarded as a "interest on interest" payment phenomenon, in this case, the capitalized amount is calculated using the compound interest rate formula. Many agribusiness investment projects are burdened with a number of natural restrictions (land size, for example, can not be increased if neighbors do not intend to sell their land; there is not much possibilities for improvement, etc.). In this case, an increasing part of the cash flow due to one investment project, investors will divert and use to initiate other, as a rule, more advanced projects.

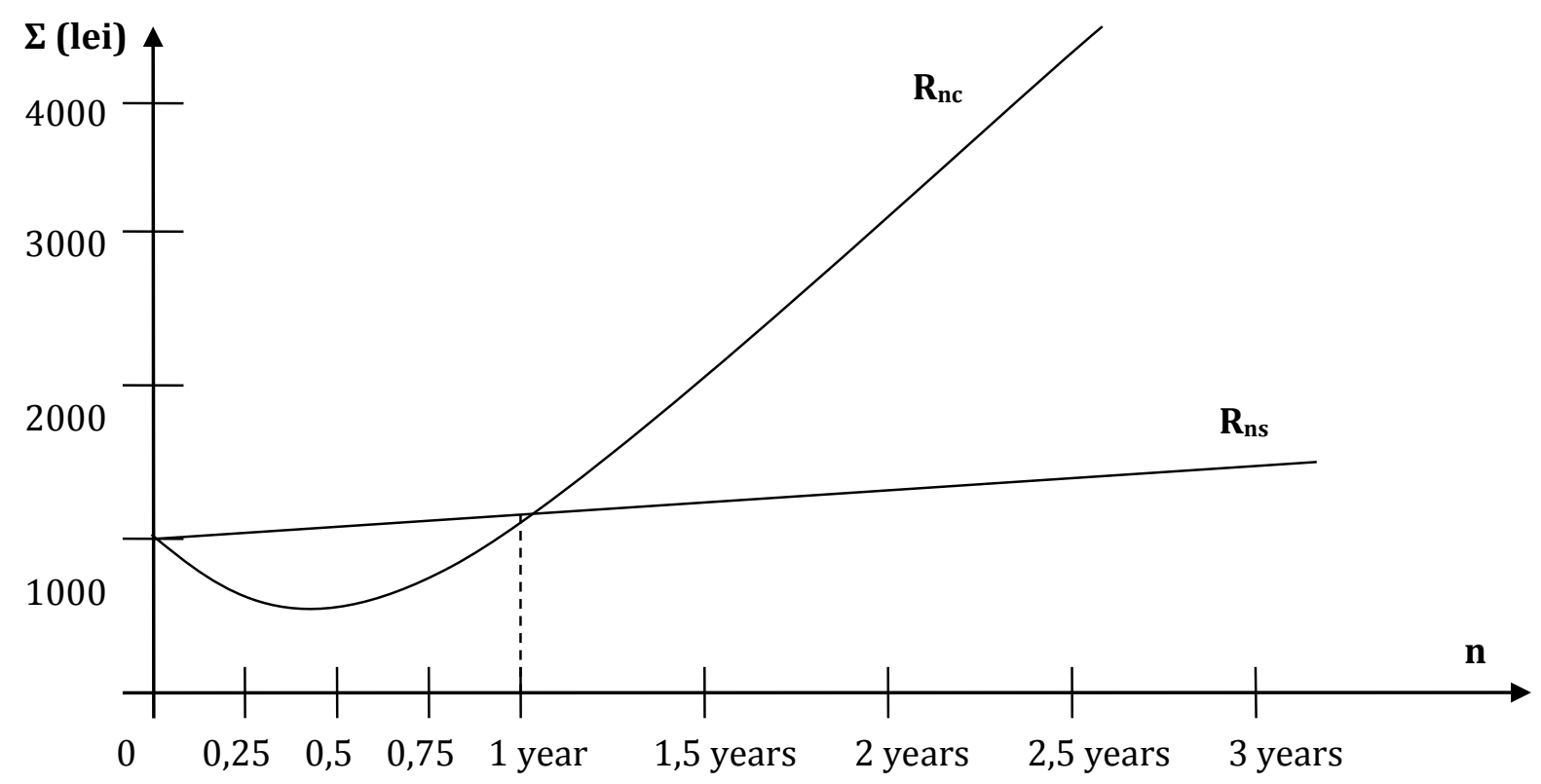
Figure 1. The difference of capitalized (future) value, depending on the number of calculation periods and methods
Source: Author`s calculations.

Depending on the specific intentions of the investor, the capitalized amount of the investment project will be calculated according to a specific algorithm, specially developed for this situation, the essence of which is reduced to the separation of financial flows, capitalized by the one or another method of calculation.

In order to simplify the algorithms, the future (capitalized), investment value of projects is calculated, as a rule, using the compound interest rate formula. At the same time, the current one, i.e. the original (initial) cost of project acts as a generator of future returnable cash flows, but is not equal to them. As a result, the future (capitalized) value of an investment project (FV) is solely a result of the capitalization of the cash flows generated by this project and is determined by the formula:

$$
F V=\sum_{n=1}^{n} P_{n} \times(1+r)^{n} \text {, lei }
$$

where:

$P_{1} ; P_{2} ; P_{3} \ldots P_{n}-$ net cash flows (net income + depreciation for depreciable components of investment projects), respectively, for the $1 \mathrm{st}, 2 \mathrm{nd}$, 3rd, etc. years of project operation, lei;

$r$ - capitalization rate, specific units;

$n-\quad$ the number of periods (for the agribusiness industries - the number of years of operation of the project).

As it was already emphasized, the calculation of the net cash flow for each year of the project's operation is carried out on the basis of technological charts, developed for each specific type of investment, based on the planned market prices and the actual (normative) cost of production. The calculation methodology, structure and current (actualized) cost of the overwhelming majority of the 
agri-food products, produced in the Republic of Moldova, are set out in the practical guide "Tariffs of Costs in Agriculture" [4].

The concept of present Value (PV), net present value (NPV) and rentability index of investments in an inflationary economy. The future (capitalized) cost of an investment project is an important criterion for making investment decisions and serves as an indispensable guideline in the case of choosing the most appropriate investment option from several alternatives. At the same time, the investor, as a rule, is interested not so much in the future value (especially in the gross future value) of the investment, but in its present value, i.e. actualized (reduced) total (based on completion of the project operation) income for the entire period of its operation. In order to identify this indicator, referred to as - the present (current) value (PV), the projected cash flows are subject to the procedure of updating (discounting). The essence of the discounting process is that instead of calculating future value (FV), analysts estimate the same cash flows from the point of view of the present moment. The calculation is carried out according to the formula:

$$
P V=\sum_{n=1}^{n} \frac{P_{n}}{(1+r)^{n}} \text { (lei) }
$$

The symbols used correspond to the formula (5).

The practical significance of the actualized (updated) value of the investment project is beyond doubt. Having determined the present value (PV), the investor practically finds out (which is very important) the market price of the project at the stage of its commissioning, calculated on the basis of updated cash flows (one of the three main methods for calculating the market price of real estate, legalized in the Republic of Moldova). It has to be mentioned that dimensions of PV is especially relevant for developers, i.e. investors whose main purpose is not so much the exploitation of investment projects, as their construction (for example, planting a garden or a vineyard plantation) with their subsequent sale.

It should be separately emphasized that from the point of view of the developer, it is important not only to know the current market value of the project, but the difference between this cost and the initial cost of its construction. In this case, along with the present value (PV), one should also calculate the net present value (NPV) using the formula:

$$
N P V=P V-I C=\sum_{n=1}^{n} \frac{P_{n}}{(1+r)^{n}}-I C \text { (lei) }
$$

The objectivity and reliability of using this algorithm is based on the fact that, being reduced by the time of the start of operation (the time the investment project is put into operation), both the initial cost of its construction and all subsequent proceeds from operation will be measured by banknotes (lei, dollar, euro, etc.), having equal purchasing power.

Achieving purchasing power parity by applying formula (9) largely depends on the validity of the calculation of the update rate. In the most general approach, the value of the actualization rate or (which is the same) the discount rate $\left(r_{d}\right)$, as well as the size of the capitalization rate $\left(r_{c}\right)$, are predetermined by: (i) inflation rates; (ii) the degree of riskiness of investing money in this particular type of business; (iii) naturally, the level of profitability of the production of these agricultural products, etc.

All these indicators, even if they are completely objective, can often have nothing to do with an investment project. Moreover, the attempts of individual authors to calculate the discount rate for a project by simple (arithmetic) summation of all previously noted indicators are devoid of logic, since all of them are subject to the effect of mutual absorption. Taking into account the fact that with relatively small absolute amounts of discount rates $\left(r_{d}\right)$ and capitalization rates $\left(r_{c}\right)$, there are practically no differences between them [3, p. 338], given the presence of instability of these rates over the years of project operation. The indicated source of information recommends calculating the average annual discount rate on the basis of generally accepted indicators in the national economy (average business lending rate, current lending rate for investment projects in a given industry, a given locality, and so on).

As noted earlier, the higher the capitalization rate, the shorter the payback period of corresponding investments, and vice versa. The reduction (on average in the banking system) of the 
lending rates of economic entities, currently taking place in the Republic of Moldova, means a general increase in the payback period of the invested funds. On the other hand, the same fact means that investments in the most profitable types of business (fuel filling stations, pharmacies, etc.) have already reached their maximum level, i.e. saturation level.

The time has come to invest in those sectors that were previously considered less attractive due to the longer payback periods of investment costs. The investment front is expanding. If at $10 \%$ of average annual efficiency all invested money could be returned to the investor within 10 years (under zero inflation conditions, naturally), then at 5\% of average annual efficiency, the return period for invested funds increases to 20 years. With "other things being equal" - means that the area of application of investment projects is becoming wider, covering more and more new sectors of the national economy, new territories, etc. To a large extent, such an expansion in the sphere of investments means the flow of capital from more profitable to less profitable sectors of the national economy.

In any case, having calculated the NPV indicator, the investor gets a clear indication of which direction to go further:

- if $\mathrm{NPV}>0$, that is measured by a positive number, which means that investments are profitable and can be implemented in practice;

- if NPV $<0$, that it has a negative value, which means that investments are unprofitable and should be abandoned;

- in a situation when NPV $=0$, this indicator receives a neutral status and must be supplemented (or replaced) with other decision-making indicators.

Along with a number of obvious and less obvious advantages, the calculation of indicators Present Value - PV and Net Present Value - NPV has some disadvantages. The main one is the fact that denoting, suppose, a positive effect from investing in such and such a project (NPV>0), this indicator confirms the presence of a positive result, but does not open the investor's eyes regarding what kind of price this result will require to be achieved. This disadvantage of NPV is particularly relevant in the case of alternatives. It is not excluded that any of them will be able to provide the investor with the same result, but at a significantly lower price, at significantly lower costs.

In order to prevent possible errors in the process of making investment decisions, it is proposed, along with the calculation of PV and NPV, to also calculate the value of the investment project profitability index (Rentability Index - RI).

$$
R I=\sum_{n=1}^{n} \frac{P_{n}}{(1+r)^{n}}: I C \quad \text { (specific units) }
$$

Taking into account that $P V=\sum_{n=1}^{n} \frac{P_{n}}{(1+r)^{n}}$ (see formula 8), we can convert formula (10) into:

$$
R I=\frac{P V}{I C} \text { (specific units) }
$$

Thus, if

- $\mathrm{RI}>1$ (PV> IC) - the market value (PV) of the investment project at the stage of its commissioning (equivalently at the stage of completion of the construction stage) is higher than the initial cost of its creation (whether it is building, planting a garden or a vineyard, irrigation system, etc.) - the investment project is accepted;

- $\quad \mathrm{RI}<1(\mathrm{PV}<\mathrm{IC})$ - the investment project should be rejected;

- in a situation when RI = 1 (PV = IC) - the index of profitability becomes neutral and must be supplemented by other calculations [3, p. 447].

In contrast to indicators, based on the absolute size of expected cash returns, which are PV and $\mathrm{NPV}$, the profitability index is relative, characterizes not the amount of income, but the level of profitability of the investment project and therefore is almost irreplaceable when choosing the most effective project from the many others. The higher the RI is, the greater, with other things being equal, will be the return on the practical implementation of the project. 
Conclusion

1. In an economic system with "zero" or near to "zero" inflation, as well as for the evaluation of investment projects with short periods of operation (2-3 years), the main indicators for investment projects' evaluation must be the payback period (Tp.p.) and the accounting rate of return (ARR).

2. For conditions of inflationary economy it has to be recommended more sophisticated methods of investment projects' evaluation, based on a preliminary calculation of net cash flows, generated by these projects, the subsequent updating of these flows and the calculation of indicators such as present value (PV), net present value (NPV) and rentability index (RI) for one or another investment project.

3. For all (without exceptions) situations, final decisions about the practical implementation of investment projects are recommended to be made on the basis of a comparison of above mentioned performance indicators for 2-3 or even more alternative projects, elaborated for the same or related branches of economic activity.

\section{REFERENCES}

1. BIROUL NAŢIONAL DE STATISTICĂ AL REPUBLICII MOLDOVA. Anuarul Statistic a Republicii Moldova, 2017 = Statističeskij ežegodnik Respubliki Moldova $=$ Statistical yearbook of the Republic of Moldova. Chişinău: Biroul Naţional de Statistică, 2017. 485 p.

2. STRATAN, A., BAJURA, T. Metodologia elaborării şi evaluării proiectelor investiţionale pentru sectorul agroalimentar: ghid metodologic. Chişinău: INCE, 2017. 70 p. ISBN 978-9975-3171-4-6.

3. KOVALËV, B.B. Vvedenie v finansovyj menedžment. Moskva: Finansy i Statistika, 1999.

4. BAJURA, T., STRATAN, A., SCOBIOALĂ, P., IGNAT, A., CEBAN, A., ROMANCIUC, A., GANDACOVA, S. TUREŢCHI, V., IAŢIŞIN, T., ARNAUT, C., ȚIRIGAN, S., LUCAŞENCO, E., POPA, N. Tarife de costuri în agricultură: ghid practic. Chişinău: INCE, 2017. 161 p. ISBN 978-9975-3171-3-9.

5. ALBU, S. Valoarea patrimoniului. Problemele aprecierii şi gestiunii. Chişinău: UTM, 2009. 184 p. ISBN 978-9975-45-120-8.

6. T TUURANU, P., STRATAN, A. Organizarea muncii şi a producţiei agricole. Chişinău: UASM, 2006. 384 p. ISBN 978-9975-64-063-3.

7. PARMAKLI, Д., MOKANU, N. Agrarnaâ èkonomika Respubliki Moldova: sostoânie i puti restrukturizacii. Kagul: KGU im. «B. P, Hašdeu», 2009. 324 s. ISBN 978-9975-4051-3-3.

8. MOCANU, N. Managementul reformărilor în sectorul agrar al Republicii Moldova. Chişinău: UASM, 2010. 217 p. ISBN 978-9975-4152-2-4.

9. TIMOFTI, E., CHIŞLARU, A. Eficiența economică a producerii grâului de toamnă în Republica Moldova. Chişinău: UASM, 2007. 223 p. ISBN 978-9975-64-095-4.

10. TIMOFTI, E., POPA, D. Eficiența mecanismului economic în sectorul agrar. Chişinău: IEFS, 2009. 343 p. ISBN 978-9975-9823-3-7.

11. UIL'ÂM, F. ŠARP, GORDON DŽ. ALEKSANDER, DŽEFFRI V. BÈJLI. Investicii. Moskva: Infra-M, 1999. $1027 \mathrm{~s}$.

12. MERTENS, A. Investicii. Kiev: Kievskoe investicionnoe agenstvo, 1997. 245 s.

13. GITMAN, L. DŽ., DŽONK, M. D. Osnovy investirovaniâ. Moskva: Izdatel'stvo Delo, 1997. 1008 s.

14. WILLIAM, Britton, KEITH, Davies, TONY, Johnson. Modern Methods of Valuation. London: The estates Gazette Limited, 1989. 768 p. ISBN 0-7282-0126-7.

15. KOVALËV, V. Metody ocenki investicionnyh proektov. Moskva: Finansy i Statistika, 1998. ISBN 5279-01871-6.

16. BIRMAN, G., ŠMIDT, S. Èkonomičeskij analiz investicioonyh proektov. Per.s angl. Pod red. L.P. Belyh. Moskva: Banki i Birži, ÛNITI, 1997. 480 s.

17. BRIGHEM, Û., GAPENSKI, L Finansovyj menedžment. Polnyj kurs. V 2-h t. Per. s angl. Pod red. V.V KOVALEVA. SPb: Èkonomičeskaâ Škola, 1997.

18. FRIDMAN, D., ORDUÈJ, N. Analiz i Ocenka prinosâsejej dohod nedvižimosti. Per. s angl. Moskva: Delo Ltd, 1995.

19. BRIGHAM, E., HOUSTON, J. Fundamentals of financial management Orlando: Harcourt College Publishers, 1999. 1034 p. ISBN 978-0030272639.

Recommended for publication: 22.03.2019 